\title{
Transatlantic Iron Connections: Education, Emotion, and the Making of a Productive Workforce in Minas Gerais, Brazil (ca. 1910-196o)
}

\author{
Irma Hadzalic
}

"The steel industry is by far the most important factor in our national economy, to the point that we can say today that the fate of the entire country is intimately linked to that of the industry." The Luxembourg sociologist and economist Jean Joseph Lentz (1906-1949) was indeed correct about the importance of the steel industry in Luxembourg in the early twentieth century. Until the mid-nineteenth century, Luxembourg had been a poor agricultural country, a country of emigration. ${ }^{2}$ The discovery of iron in the 1850 os accelerated the country's economic growth, and by the beginning of the twentieth century Luxembourg had become the fifth largest iron producing country in the world. Its most prominent steel producer, ARBED, founded in 1911, became Luxembourg's "machine of progress" whose motor depended on a workforce that did not yet exist. ${ }^{3}$ Lured by the promises of this fast-growing industry, German, Italian, and later Portuguese laborers

1 Jean J. Lentz, La lutte contre la tuberculose dans le Grand-Duché de Luxembourg: Etude sociale et recueil des textes (Luxembourg: Imprimerie de la Cour Joseph Beffort, 1934), 13. Unless otherwise noted, all translations are the author's.

2 For a short summary of the different waves of Luxembourgian emigration to the Americas, see Claude Wey, "L'histoire des migrations entre le Luxembourg et les Amériques," in Retour de Babel: itinéraires, mémoires et citoyenneté (Luxembourg: Éditions Retour de Babel, 2007), 31-40.

3 ARBED was the result of a merger of the Burbach, Eich, and Dudelange steel producing companies. For a more detailed history of the mergers of steel companies, see Gustavo Lins Ribeiro, "Learning from Minas Gerais: Flows of Capital, Production, and Managerial Models Within the Steel Industry," in Industry and Work in Contemporary Capitalism: Global Models, Local Lives?, ed. Victoria Goddard and Susana Narotzky (London: Routledge, 2015), 91-104; Félix Chomé, ARBED: Un demi-siècle d'histoire industrielle 1911-1964 (Luxembourg: ARBED, 1972). ARBED is described as the "machine of progress" in a newspaper article on an excursion of Luxembourg orphans (Rhamkinder) to the open-air schools created by ARBED; see "Ausflug der Rhamkinder ins Minettebassin," Luxemburger Wort, July 9, 1949. 
came to the country's rescue. ${ }^{4}$ From a country of emigration, Luxembourg transformed itself into a magnet for immigrants, and its southern industrial parts doubled in population between 1890 and $1910 .{ }^{5}$ In the first decade of the twentieth century, more than half of Luxembourg's population was employed in the steel-making business. This created new challenges, such as providing sufficient and appropriate housing and health facilities as well as education and training for the workers and their children. Fully aware that the future of their company to a large extent depended on their workers' well-being, ARBED's leaders launched a series of social initiatives to improve the lives of their employees. They understood that a skilled and healthy workforce would ultimately have a positive effect on the company's financial situation.

Across the Atlantic Ocean, in Brazil, there was an equally strong demand and need to build up the steel industry. Plans to develop and modernize steel production were of major importance to the Brazilian political elite of the time, but their implementation posed serious dilemmas. While Brazil's soil was rich in iron-especially in the Minas Gerais region-technological and expertise problems persisted. A small steel company called Companhia Siderúrgica Mineira was created in 1917 in the city of Sabará in Minas Gerais, but given its lack of technological know-how, and with the national market relying only on imported products, it was doomed to fail. Moreover, Brazilian politicians were fighting the North American monopoly over the steel market and thus desperately looking for other investors. ${ }^{6}$ Since ARBED, at the time, was planning to expand to other continents, the idea to cooperate with Brazilian steel producers was quickly realized through the creation, in 1921, of the Companhia Siderúrgica Belgo-Mineira in Sabará, Minas Gerais. ${ }^{7}$ As we will see in this chapter, ARBED's leaders not only brought their steel producing expertise to Brazil but also their Luxembourgian ideas of social welfare. One engineer in particular, Louis Jacques Ensch (1895-1953), was highly influential in disseminating and implementing these ideas.

While much has been written about ARBED's social initiatives in Luxembourg, there has been little research on the company's influence on social

4 For more information on (Italian) immigration to Luxembourg, see Antoinette Reuter and Claudio Cicotti, Rêves d'Italie, Italies de rêve: Imaginaires et réalités autour de la présence italienne au Luxembourg et dans la Grande Région (Luxembourg: University of Luxembourg, 2008).

5 Ben Fayot, "Merci au 'Minettsdapp'!, Forum 304 (2011): 39.

6 See, for example, François Moyen, A história da Companhia Siderúrgica Belgo-Mineira: Uma trajetoria de crescimento consistente (1921-2005) (Belo Horizonte: Acelor Brasil, 2007); Antonio José Polanczyk, Louis Ensch e a Belgo-Mineira (Belo Horizonte: 3i Editora, 2014).

7 I will use the abbreviated form "Belgo-Mineira" throughout the text. 
reforms in the rest of the world. Until recently, studies of ARBED's global influence mostly dealt with the economic aspects of the company's expansion to Latin America, paying little attention to its social initiatives. Even though several researchers briefly mention the social initiatives created by ARBED in the Brazilian state of Minas Gerais, they do not generally make them the focus of their analysis, nor do they link them to the company's social initiatives in Luxembourg. ${ }^{8}$ Moreover, research on Belgo-Mineira and its connection with ARBED is almost entirely the domain of Brazilian historians, architects, and engineers working and writing in Portuguese. ${ }^{9}$

This essay attempts to close some of the gaps in the research. Focusing on the social aspects of ARBED's expansion abroad, it argues that the Luxembourg and European social models were exported to Minas Gerais after the establishment of Belgo-Mineira. It aims to show the similarities between the social welfare ideas in the two countries and take a closer look at the means, methods, and motives used in the implementation of these ideas. To this end, this paper draws on two sets of primary sources: The first consists of twentyfive handwritten stories written by former Belgo-Mineira employees. These were gathered in 2007 as part of a "concurso de memória empresarial" (work memories contest) called "Foi assim" (That's how it was) organized by the archivists of the Centro de Memória da ArcelorMittal Brasil in Sabará. ${ }^{10}$ In this

8 A possible exception is Fabio José Martins de Lima's doctoral dissertation from 2003, which discusses the architectural innovations and urban planning of the industrial cities created by Luxembourgers in Minas Gerais while also showing examples of ARBED's industrial villages in Luxembourg; see Fabio José Martins de Lima, "Por uma cidade moderna: Ideários de urbanismo em jogo no concurso para Monlevade e a realização da nova cidade operária (1931-1943)" (PhD diss., University of São Paulo, 2003).

9 See, for example, Osias Ribeiro Neves and Marina Mesquita Camisasca, Aço Brasil: uma viagem pela indústria do aço (Belo Horizonte: Escritório de Histórias, 2013); Telma de Barros Correia, Modernismo e o núcleo fabril: O Anteprojeto de Lucio Costa para Monlevade (paper presented at the vi Seminário de História da Cidade e do Urbanismo, Natal, Brazil, 200o); Gustavo Barros, "O desenvolvimento do setor siderúrgico brasileiro entre 1900 e 1940: criação de empresas e evolução da capacidade produtiva," Revista de Historia Econômica \& Economia Regional Aplicada 9, no. 14 (Jan-Jun 2013): 9-32; Fernanda Bueno, "Estruturas metálicas do inicio do período do industrialização em Minas Gerias: Decorrências e preservação" (master's thesis, Federal University of Ouro Preto, 2012); Carvalho de I. Menezes, "Louis Jacques Ensch: A presença do engenheiro luxemburguês em Sabara," Revista do Instituto Histórico e Geográfico do Ciclo do Ouro 1, no. 1 (December 2011): $72-77$.

10 The Centro de Memória da ArcelorMittal Brasil in Sabará is a foundation and an archive dedicated to the preservation of the industrial past in the Minas Gerais region and started operating in 2000. The archive is rich in audio-visual and textual documents, but the existing documents are still uncatalogued, unlisted, and uncoded. This is why I refer to these documents by title only (for example, O Pioneiro or "Foi assim"). 
competition, correspondents were asked to write an essay about their experience working for Belgo-Mineira. The second set of sources is taken from Belgo-Mineira's magazine $O$ Pioneiro, published twice a month between 1954 and 1965. In each issue, one or several workers are presented textually and visually in a section dedicated to the "Velha Guarda"-Belgo-Mineira's "old guard." Taking into consideration that these sources are representing the image that the company wanted to project to the world, it is necessary to adopt a critical approach. Hence, my analysis takes as its critical standpoint Foucault's concept of the "technologies of power." Simply put, Foucault sees power as ways of making people behave in a certain way, which, as we will see, was central to the creation of Belgo-Mineira's obedient workforce. ${ }^{11}$

In an attempt to unveil the circumstances that led to the establishment of business connections between Luxembourg and Brazil and to analyze the impact of these connections, this paper unfolds in three parts. The first part briefly discusses the creation of ARBED and its social reforms in Luxembourg. In the second part, I will describe the context in which Belgo-Mineira was created in Brazil and the attempts of the company's director, Louis Jacques Ensch, to develop both the mining industry and a variety of social initiatives in Brazil. The third and final part emphasizes the importance of workers' education through social initiatives and takes a closer look at the creation of emotions such as fear, pride, and belonging as strategies to control and discipline the workforce. The paper closes with a discussion of the company's extensive intervention into the workers' private lives and of the implications of this intervention.

\section{ARBED's Social Initiatives in Luxembourg}

In order to talk about and understand ARBED's significance, it is necessary to look at the company's visionary and liberal founding family, the Mayrischs. It was the Mayrischs who pioneered the social initiatives that not only changed the lives of the people who worked for the company but greatly influenced the lives of the entire population of Luxembourg. ${ }^{2}$ Due to their social engagement, ARBED's founding director Emile Mayrisch (1862-1928), his wife Aline Mayrisch de Saint-Hubert (1874-1947), and their daughter Andrée Viénot (1901-1976)

11 Michel Foucault, Power/Knowledge: Selected Interviews and Other Writings, 1972-1977, trans. Colin Gordon (New York: Pantheon, 1980).

12 The Mayrischs' social initiatives are described in ARBED, OEuvres sociales (Luxembourg: Victor Bück, 1922), a promotional booklet published by the company. 
became the most influential, respected, and mythologized Luxembourgers. This mythologization was probably strengthened by the Mayrischs' close connections to the leading political and literary circles in Europe and beyond. Besides intellectual exchanges with the elites of the time, which often took place at their Colpach Castle in Luxembourg, the Mayrischs were also eager travelers, which meant that their ideas of social welfare were also informed by intellectual trends and tendencies abroad. ${ }^{13}$

While the main focus of this chapter is on how the Mayrischs' approach of generating economic gain through social initiatives was applied in Brazil, it is necessary first to briefly describe some of their social initiatives in Luxembourg in order to understand the similarities between the social welfare ideas in the two countries. Probably the most visible initiatives were those that involved the betterment of housing conditions. Before ARBED's involvement, much of Luxembourg's population lived in dwellings that "resembled a barn rather than a human habitation," as Aline Mayrisch wrote in a 1907 report on living conditions in Luxembourg. ${ }^{4}$ To improve the living and health conditions of its workers, ARBED built the so-called "cités ouvrières" (workers' housing estates) in the southern part of Luxembourg. ${ }^{15}$ These were available to workers for a very modest rent. Modeled on the German company Krupp's industrial city, ${ }^{16}$ and reflecting the hierarchical structure of the company

13 See, for example, Karin Priem and Geert Thyssen, "Fragmented Utopia: Luxembourgian Industrialists, Intellectual Networks and Social-Educational Reforms between Tradition and Avant-Garde," Jahrbuch für Historische Bildungsforschung 19 (2013): 106-26; Robert Stumper, Colpach (Luxembourg: Amis de Colpach, 1957); Robert Stumper, Colpach, 2nd, rev. and exp. ed. (Luxembourg: Amis de Colpach, 1978); Germaine Goetzinger, Aline Mayrisch: Féministe engagée, philanthrope éclairée, femme de lettres éminente (Metz: n.p., 2014); Klaus Dittrich, "Buddhism, Business, and Red-Cross Diplomacy: Aline Mayrisch de Saint-Hubert's Journeys to East Asia in the Interwar Period" (in this volume). For more information on the correlation between capitalism and intellectual networks, see Geert Thyssen and Karin Priem, "Brains, Money and Power in Education: Industrial-Intellectual 'Avant-Gardes' and Their 'Social Works'” (unpublished conference paper, International Standing Conference for the History of Education [ISCHE] 35, Riga, Latvia, August 21-24, 2013).

14 Société luxembourgeoise d'hygiène sociale et scolaire, Einiges über Wohnungsverhältnisse der ärmeren Arbeiterbevölkerung in Luxemburg (Luxembourg: M. Huss, 1907), 12.

15 See Antoinette Lorang, L'image sociale de l'Arbed à travers les collections du Fonds de logement (Luxembourg: Le fonds pour le développement du logement et de l'habitat, 2009), 38.

16 Ibid., 9. For more information on industrialization in Germany and the Krupp conglomerates, see Walter Buschmann, Zwischen Rhein-Ruhr und Maas: Pionierland der Industrialisierung - Werkstatt der Industriekultur (Essen: Klartext, 2013); Lothar Gall, Krupp: Der Aufstieg eines Industrieimperiums (Berlin: Siedler, 200o). 
(the higher the rank, the bigger and better the house), these housing solutions also served to increase workers' loyalty to the company. ${ }^{17}$

Health initiatives were another means of gaining workers' loyalty. The health of their workers and their workers' children was of particular concern to the Mayrischs. For them, it was a logical move to attend also to the children who would become the future working elite. ${ }^{18}$ Shortly after ARBED's establishment, the company began to initiate many health initiatives for children, especially those suffering from tuberculosis-including open air schools, preventoriums, holiday camps, milk distribution stations, and scouts troops. These initiatives were characterized by strict rules and schedules and thus focused on disciplining and controlling "sick and weak" children. ${ }^{19}$ The health of children and adults was also promoted through the activities of the Ligue luxembourgeoise contre la tuberculose (Luxembourg Anti-Tuberculosis League), its sanatoriums, visiting nurses, and dispensaries. ${ }^{20}$ Aline Mayrisch deserves the biggest credit for these health initiatives. Attention to physical education was also a major part of the curriculum of vocational schools. The best-known of these schools was the Institut Emile Metz, featuring, among other things, a scouts troop and a gym club to further the "moral and physical development of the working class."21 In short, ARBED's directors did not hesitate to invest in the

17 Lorang, L'image sociale de l'Arbed, 30-34. See also Antoinette Lorang, "Les logements ouvriers: une cité modèle à Dudelange/A Model Workers' Housing Estate in Dudelange," in La sidérurgie luxembourgeoise: Un siècle d'histoire et d'innovation/Steelmaking in Luxembourg: A Century of History and Innovation, ed. ArcelorMittal (Luxembourg: ArcelorMittal, 2011), 153-55.

18 Frederik Herman, "Forging Harmony in the Social Organism: Industry and the Power of Psychometric Techniques," History of Education 43, no. 5 (2014): 611.

19 For more information on ARBED's open-air schools, see Geert Thyssen, "Engineered Communities? Industry, Open-Air Schools, and Imaginaries of Belonging (c. 1913-1963)," History of Education \& Children's Literature 10, no. 2 (2015): 297-320; Geert Thyssen, "The Open-Air Schools of Dudelange and Esch-sur-Alzette," Forum für Politik, Gesellschaft und Kultur 301 (2010): 40-42; Irma Hadzalic, "Sick and Weak but Made of Steel: Luxembourgian Open-Air Schools and Other Responses to the Spread of Tuberculosis at the Beginning of the 2oth Century," Revista de História e Historiografia da Educação 1, no. 1 (2017): 44-64.

20 The fight against tuberculosis in Luxembourg is comprehensively described in Enric Novella, "Germs, Bodies, and Selves: Tuberculosis, Social Government, and the Promotion of Health-Conscious Behavior in the Early Twentieth Century" (in this volume).

21 "Historique," Lycée Technique Privé Emile Metz, http://www.ltpem.lu/php_links/historique.php. The history of the institute is nicely described by Françoise Poos, see "Photography as Space for Constructing Subjectivities: Luxembourg's Steel Dynasties and the Modern Workforce as Seen through the Glass Plate Negatives from the Institut Emile Metz" (in this volume). For more information on the Institut Emile Metz and an examination of the psychometric techniques developed for vocational orientation, see Herman, "Forging Harmony in the Social Organism." 
health of their workers and in the education and training of their workers' children to create a productive and skilled workforce for the manufacture of highquality products. ${ }^{22}$

ARBED's social engagements were not exclusively altruistic or philanthropic, however. On the surface, they served to "elevate workers' moral and intellectual level," but in practice the Mayrischs understood that improving the miners' living and working conditions would also improve their productivity. ${ }^{23} \mathrm{ARBED}$ used its social initiatives to educate its workers and to teach them loyalty to the company, ultimately assuring the company's economic profit. ${ }^{24}$ ARBED's leaders took pride in and widely publicized their housing, health, education, and other social initiatives through, at the time, innovative tools and media, such as photography and film..$^{25} \mathrm{~A}$ lot of research has shown that ARBED was fully engaged in every sphere of life in Luxembourg. ${ }^{26}$ Employing more than half of Luxembourg's population and investing heavily in social improvements, ARBED became the most important company in the country, from its establishment in 1911 until the world economic crisis in the 1970s.

Even so, the company's path towards economic and social prosperity was not always smooth. In fact, it was moments of crisis and stagnation during and after the First World War that made possible ARBED's expansion and sealed the ties between Luxembourg and Brazil. Right after its occupation by Germany in World War I, Luxembourg in 1919 withdrew from the German Customs

22 See Jean Marx, "L'ARBED, un pionnier de la formation professionnelle au Luxembourg/ ARBED, a Pioneer of Professional Training in Luxembourg," in ArcelorMittal, La sidérurgie luxembourgeoise, $161-63$.

23 Andrée Mayrisch, cited in Nadine Schmitz, "Le paternalisme d'Émile Mayrisch," in Terres rouges: Histoire de la sidérurgie luxembourgeoise, vol. 3, ed. Charles Barthel and Josée Kirps (Luxembourg: Centre d'études et de recherches européennes Robert Schuman/Archives nationales de Luxembourg, 2011), 104-5. Conducting a social survey at ARBED in 1928, entitled Plan de développement pour les oeuvres sociales d'Arbed-Terres Rouges, Andrée Mayrisch, Emile Mayrisch's daughter who worked in the company's central administration, concluded that the workers' well-being depended first and foremost on their salary. Because a rise in salary was not possible, Andrée suggested social works as one alternative to improve workers' well-being.

24 Nadine Schmitz, "La politique sociale de l'ARbed/Arbed's Social Policy," in ArcelorMittal, La sidérurgie luxembourgeoise, 149-51.

25 In this context, Herman and Plein talk about "new technologies of display" serving as educational tools. See Frederik Herman and Ira Plein, "Envisioning the Industrial Present: Pathways of Cultural Learning in Luxembourg (1880s-1920s)," Paedagogica Historica 53, no. 3 (2017): 268-84.

26 See, e.g., Charles Barthel and Josée Kirps, eds., Terres Rouges: Histoire de la sidérurgie luxembourgeoise, 6 vols. (Luxembourg: Centre d'études et de recherches européennes Robert Schuman/Archives nationales de Luxembourg, 2009-2018). 
Union and in 1921 entered into an economic union with Belgium. Following these changes and disruptions, ARBED desperately looked for new mining sources and export markets. ${ }^{27}$ At the same time, Brazil, too, sought to modernize and expand its steel industry and welcomed ARBED with open arms. By expanding to Brazil, ARBED exported not only its steel producing expertise but also its social welfare ideas, adapting them to a new country and a new context.

\section{Luxembourg-Brazilian Cooperation}

The development of the steel industry was a major concern for Brazilian government representatives, such as President Epitácio Pessoa (1865-1942), "the forceful patron of industrialization," and his successor Arthur Bernardes (1875-1955), who sought to boost national steel production by attracting foreign investors. ${ }^{28}$ In 1920, the Belgian King Albert I (1875-1934) traveled to Brazil, where he was welcomed by President Bernardes. The Brazilian president explained to the Belgian king that the Brazilian steel production industry was in desperate need of European investors. ${ }^{29}$ Upon his return to Europe, King Albert I passed on this message to his economic advisor Gaston Barbanson (1876-1946) who was also one of ARBED's directors. ${ }^{30}$ As mentioned above, Luxembourg's exit from the German Customs Union in 1919 had complicated ARBED's export plans, making expansion to Latin America a welcome and convenient proposition. The company leaders therefore did not waste time implementing this idea. Only a few months after King Albert I's return to Europe, Émile Mayrisch and Gaston Barbanson in 1920 formed the Syndicat de Brésil (Brazil Syndicate) to study the possibility of developing steel companies

27 At the same time, ARBED also expanded to Asia, notably to Japan. See Klaus Dittrich, "Selling Luxembourgian Steel in Japan: Columeta Tokyo, 1925 to 1941," Zeitschrift für Unternehmensgeschichte 61, no. 2 (2016): 215-36.

28 Eddy Stols, "Présences belges et luxembourgeoises dans la modernisation et l'industrialisation du Brésil (1830-1940)," in Brasil: Cultures and Economies of Four Continents, ed. Bart de Prins, Eddy Stols, and Johan Verberckmoes (Leuven: Uitgeverij Acco, 2011), 147.

29 By establishing their own companies in Brazil, European investors would help Brazilian officials to break the North American monopoly on steel production. President Bernardes strongly opposed the plans by U.S. businessman Percival Farquhar for the Itabira Iron Ore Company, which threatened to take over Brazilian steel production. See Moyen, A história da Companhia Siderúrgica Belgo-Mineira, 23.

Stols, "Présences belges et luxembourgeoises," 150-51. 
and other businesses in Brazil and elsewhere in South America. ${ }^{31}$ In 1921, ARBED merged with the already existing Companhia Siderúrgica Mineira to form the new Companhia Siderúrgica Belgo-Mineira, investing 15,000 conto into the new company, a significant investment comprising about 25 percent of the entire state revenue of Minas Gerais. ${ }^{32}$

If ARBED's creation in 1911 marked a milestone in the history of modern Luxembourg, the creation of the Companhia Siderúrgica Belgo-Mineira in Minas Gerais a decade later definitely changed the course of the Brazilian history of steel production. ${ }^{33}$ However, the first six years of the Luxembourg-Brazilian cooperation gave much cause for concern and led ARBED to question its initial enthusiasm. With no export plans and no marketing strategies in place, the newly established Belgo-Mineira ran a constant deficit. Therefore, the young engineer Louis Jacques Ensch was sent on a mission in $1927 .^{34}$

Before embarking on his Brazilian adventure, Ensch lived and worked in Luxembourg's industrial south. His entire life, education, and career were connected to ARBED and steel production. An optimistic, dynamic, and knowledgeable engineer, Ensch became production manager of ARBED at the age of $25 .{ }^{35}$ Working hand in hand with ARBED's directors, he observed their leadership skills and their preoccupation with their workers' well-being and dreamed of becoming one of these great industrialists. ${ }^{36}$ An adventurous person, he did not hesitate to jump at the opportunity to be a new pioneer, even if this opportunity took him far away from home. ${ }^{37}$ In October 1927, ARBED thus sent its most highly skilled engineer to Brazil. As chief engineer, Ensch was put in

31 Minas Gerais was, at the time, the second most powerful state in Brazil in economic terms. See Moyen, A história da Companhia Siderúrgica Belgo-Mineira, 34.

32 See also Ribeiro, Learning from Minas Gerais, 95-100. Minas Gerais' state revenue was 60 million escudos, with 1,00o escudos equalling 1 conto; see Moyen, $A$ história da Companhia Siderúrgica Belgo-Mineira, 35 .

33 Gilbert Trausch, L'ARBED dans la société luxembourgeoise (Luxembourg: Imprimerie de la Cour Victor Buck, 2000), 9.

34 Moyen claims that Ensch was sent to cancel Arbed's deal with Brazil; see Moyen, $A$ história da Companhia Siderúrgica Belgo-Mineira, 47. But no documentation has yet been found to support this claim.

35 See Polanczyk, Louis Ensch e a Belgo-Mineira; Joseph Petit, Un grand Luxembourgeois: Louis Ensch (Luxembourg: Impr. P. Linden, 1953).

36 Ensch's personality is nicely described in a historical novel; see Marc André Meyers, D'amour et d'acier: Quand le Luxembourg et le Brésil forgeaient l'histoire (Luxembourg: Ed. Saint-Paul, 2015).

37 See Édio Vieira de Azevedo, Relances da Belgo-Mineira (Belo Horizonte: MG—SEGRAC, 2004), 23 . 
charge of Belgo-Mineira's administrative and manufacturing services. Already in 1929, he became one of the company's directors and from 1936 until his death in 1953, he held the position of the company's general director. ${ }^{38}$

Upon his arrival in the Brazilian city of Sabará, Ensch witnessed first-hand the problems the company was facing, including unqualified staff, stagnating steel production, and the accumulated stocks of steel products. Sabará, however, enjoyed a good geographical location, close to the sources of coal. According to ARBED's original plan, the Sabará plant was meant to be an experimental phase only, a sort of staff training ground until a bigger and more modern plant could be built in the city of João Monlevade, some sixty miles further east. The construction of the João Monlevade plant depended on a planned railroad that would connect Minas Gerais to the capital and the ports and thus be key for the "stimulation of the [region's] industrial development." 39 Unfortunately, with the political unrest taking place during the regime of President Getúlio Vargas, whose government had promised to build the much-needed railroad, Belgo-Mineira's plan of expansion to João Monlevade had to be postponed. ${ }^{40}$ Ensch, however, was convinced that the company would thrive by applying Luxembourgian ideas of industrial growth. In order to succeed, he considered it indispensable to deliver a high-quality product, which could only be produced by well-trained workers. Ensch thus had to, first, create training and social facilities for the workers and, second, establish mutually beneficial and meaningful relationships with the Brazilian elites who were interested in the development of the national steel industry. ${ }^{41} \mathrm{He}$ knew that steel products were in high demand during that period in Brazilian history which came to be called the "Era Dourada" - the Brazilian Belle Époque that was characterized by technological developments and major societal and cultural changes. All he had

38 Moyen, A história da Companhia Siderúrgica Belgo-Mineira, 192-93.

39 Ribeiro, Learning from Minas Gerais, 93.

40 Getúlio Vargas was a strong proponent of industrialization in Brazil. From 1937 until 1945, he instituted the corporatist regime known as "Estado Novo" (New State), the dictatorial period in Brazilian history that resulted in many unrests and changes. See Robert M. Levine, Father of the Poor? Vargas and His Era (Cambridge: Cambridge University Press, 1998). For a more critical view of Vargas and his populist ideas, see Joel Wolfe, "Father of the Poor' or 'Mother of the Rich'? Getúlio Vargas, Industrial Workers, and Construction of Class, Gender, and Populism in Sao Paulo, 1930-1954," Radical History Review 58 (1994): 80-111.

41 Ensch also had close relationships with European and North American industrialists, ambassadors, and politicians. See the folder entitled "Correspondence avec Louis J. Ensch 1941-1954," AE-AW-0040, Archives nationales de Luxembourg (ANLux). 
to do was find a way to sell Belgo-Mineira's products nationwide and to convince potential clients of their superior quality. ${ }^{42}$

During the first ten years of his directorship, Ensch turned the city of Sabará into a prosperous steel-producing environment, and the company finally started to make significant profits. Radically modifying the company's administrative system, Ensch managed to expand the plant, sell its products on the national market and even export them outside Brazil. In the early 1930s, Ensch also became friends with President Getúlio Vargas, who had similar ideas about industrialization and corporate management. Ensch was a savvy businessman, and his "powers of persuasion and his skills at arguing" ultimately contributed to the success of Belgo-Mineira, especially of its João Monlevade plant. ${ }^{43}$

\section{Education, Emotion, and the Making of a Productive Labor Force}

Already in Sabará, Ensch launched a variety of social initiatives-he ordered the construction of workers' houses and health facilities and provided onsite worker training — but it seems that Sabará served primarily as a training ground not only for his workers but also for himself. ${ }^{44}$ One of Ensch's biggest problems was "controlling" his workforce and making sure that his workers showed up for work. As one historian has pointed out, given the "lack of industrial mentality, the workers would fail to show up during the dry season, preferring to dedicate their time to the harvest." ${ }^{45}$ There were no proper living, health, educational, and leisure facilities - that is, no infrastructure that would keep the workers at the factory and at work, even though the company offered rewards for their productivity and attendance. ${ }^{46}$ So, Ensch's first challenge in Sabará was to generate an "industrial spirit" in order to overcome the workers' "passive resistance" and keep them at work. ${ }^{47} \mathrm{He}$ would do so by using his

42 One of the difficulties for Belgo-Mineira was the population's lack of trust in national products. Brazilians were used to imported products. Public opinion changed when a well-known major newspaper, $A$ Noite, used Belgo-Mineira's materials to build its new headquarters in Rio de Janeiro in 1937; see Moyen, A história da Companhia Siderúrgica Belgo-Mineira, 5 .

"Louis Ensch," Atualidades do Vale do Piracicaba. Orgâo da Associaçâo Monlevade de Serviços Sociais 150 (1971): 48.

44 See also Chômé, Un demi-siècle, 84.

45 Moyen, A história da Companhia Siderúrgica Belgo-Mineira, 59.

46 Ibid.

47 Foucault, Power/Knowledge, 163. 
personal involvement and meritocratic approaches as strategies of power and discipline. ${ }^{48}$

Due to Ensch's "philanthrocapitalism," Belgo-Mineira eventually became the biggest steel producer in Latin America. ${ }^{49}$ August 31, 1935, the day when the cornerstone was laid for the João Monlevade plant in the presence of President Getúlio Vargas, marked the beginning of a new phase in the history of steel production in Brazil..$^{50}$ That same day, Vargas also inaugurated the longawaited railroad. The railroad made it possible to import the materials needed for the construction of the industrial city of João Monlevade as well as to export Belgo-Mineira's products, connecting the newly constructed industrial area to the rest of the region and the world. As Félix Chômé, chairman of the board of directors of ARBED from 1952 until 1961, would emphasize later,

His [Ensch's] greatest work remains the creation of the Monlevade plant ... He created ... a modern steel assembly that can be regarded as a model and as the starting point of the growth of the steel industry in Brazil. Those like me who have had the privilege of visiting Monlevade, its plant, its houses, its hospital, its schools, the entire remarkable ensemble, were seized with admiration for the great work accomplished. ${ }^{51}$

João Monlevade was thus the prototype for Brazil's modern steel production. The transformation of the area into a successful steel producing environment happened rather rapidly. Before Ensch's arrival, the area was uninhabited and devoid of any infrastructure. Within a seven-year period, from 1937 until 1944, Belgo-Mineira built four blast furnaces (one of them was named after Getúlio

48 Ibid.

49 A term coined by Matthew Bishop and Michael Green in 2008, "philanthrocapitalism" refers to the combination of money, business skills, and business methods. The "philanthrocapitalists" are often personally involved in the projects they are financing. See Hugo Sintes, Review of Philanthrocapitalism: How the Rich Can Save the World and Why We Should Let Them, by Matthew Bishop and Michael Green, and Just Another Emperor? The Myths and Realities of Philanthropic Capitalism, by Michael Edwards, Development in Practice 19, no. 6 (2009): 812-15. Belgo-Mineira produced 6o percent of Brazilian steel as early as 1940, thus becoming the largest steel company in Latin America; see Stols, "Présences belges et luxembourgeoises," 154.

50 Moyen, A história da Companhia Siderúrgica Belgo-Mineira, 51. The plant was named "Usina Barbanson" in honor of Gaston Barbanson, co-founder of ARBED and also one of the founders of Belgo-Mineira.

51 A Memória de Louis Jacques Ensch (Belo Horizonte: Establecimentos Graficos Santa Maria, 1953), 63-64. 
Vargas) and spawned an entire city that was eventually described as a "dream come true and an utopia become apotheosis."52 João Monlevade became the first planned city in Brazil, most probably modeled on Krupp's workers' settlement in Essen, Germany. ${ }^{53}$ As mentioned before, Krupp's company housing also served as the model for workers' housing in Luxembourg. Hence, Ensch could draw on existing models and traditions, while organizing and designing the city according to his own plans. Ensch hired well-known architects and engineers, such as Yaro Burian and Lincoln Continentino, to design his utopian industrial city, but the execution of the construction works was his responsibility. ${ }^{54}$ The idea of a city that would "exude the joy of living and the contentment of its inhabitants, giving a clear and cheerful impression" testifies to Ensch's utopian vision of creating a peaceful, contented, and productive industrial community. ${ }^{55}$ The entire city of João Monlevade became an extension of the company, remaining under the private ownership of the company's leaders until the mid-196os.

By 1953, around 2,500 houses for the company's employees had been built in the vicinity of the plant and given to workers for free, but under strict rules of maintenance controlled by Ensch personally. He regularly inspected the hygienic conditions of the workers' houses, and if the house was not up to his, Ensch's, standards of cleanliness, the house would be taken away from the worker with the remark that "knowing how to live in a house is a way of education."56

52 Edmundo da Luz Pinto, at the 25th anniversary celebrations of Louis Ensch's administration, cited in Companhia Siderurgica Belgo Mineira (Rio de Janeiro: Graficos Bloch, 1953), n.p.

53 Aerial photographs of both cities show major similarities, and while oral histories suggest that Ensch used Essen as a model for his city, we do not yet have any documented confirmation. On Krupp's workers' settlements, see Cedric Bolz, "Constructing Heimat in the Ruhr Valley: Assessing the Historical Significance of Krupp Company Housing from Its Origins through the National Socialist Era, 1855-1941" (PhD diss., University of Victoria, 2003). Nevertheless, industrial cities were not a novelty at the time. Throughout the nineteenth and twentieth centuries, many industrial cities developed around the world, for example, Pullman in Chicago and New Lanark near Glasgow. See John Minnery, "Model Industrial Settlements and Their Continuing Governance," Planning Perspectives 27, no. 2 (April 2012): 309-21; Robert Lewis, "Networks and the Industrial Metropolis: Chicago's Calumet District, 1870-1940," in Industrial Cities: History and Future, ed. Clemens Zimmermann (Frankfurt: Campus Verlag, 2013), 89-114.

54 For more information on Yaro Burian, see Polanczyk, Louis Ensch e a Belgo-Mineira, 136. Lincoln Continentino's project is described in Fabio Jose Martins de Lima, “Urbanismo em Minas Gerais: Olhares de engenheiros, arquitetos, geógrafos e outros planejadores (1930-1980)," URBANA, Dossiê: Urbanistas e Urbanismo 5, no. 6 (March 2013):148-69.

55 Lima, Por uma cidade moderna, 98.

56 Édio Vieira Azevedo, interview by Isabella Menezes, Belo Horizonte, MG, Brazil, September 2002, transcript, Centro de Memória da ArcelorMittal Brasil, Sabará. Azevedo, head 
Through his personal and explicit involvement, Ensch not only wanted to educate the workers about hygienic principles but also instill in them a fear of deprivation, which would teach them to be docile, obedient, and respectful. Through his "inspecting gaze," Ensch could use this fear of deprivation as a "continuous technology of power" to control and discipline his workers. ${ }^{57}$ By intruding into the workers' private lives and telling them how they should live, the company used its housing initiatives as educational tools. ${ }^{58}$ The "educationalization" of workers' living spaces thus became another technology of power-a means of adapting a disciplined, obedient, and productive workforce to the needs of a modern steel company. ${ }^{59}$ Moreover, the location and size of the houses reproduced the corporate hierarchy, mirroring the skill level and social status of the workers- just as in Luxembourg. ${ }^{60}$ It is interesting to note that while Belgo-Mineira's workers came from a wide variety of national and racial backgrounds (see fig. 7.1), any form of discrimination that occurred was on the basis of workers' professional skills and abilities. ${ }^{61}$ Most of the skilled labor, however, was done by Europeans, which meant that Europeans also had better housing.

Whereas the Brazilian workers were considered to be 'simple' men without education and experience, the foreigners were the 'skilled' workers able to teach the local workforce. ${ }^{62}$

of electrical maintenance at Belgo-Mineira in the late 1940s, describes Ensch's personal and authoritarian involvement in the social initiatives and how he went inspecting the "cafuas," the workers' houses. Ensch's visits to the workers' houses are described more mildly in Azevedo, Relances da Belgo-Mineira, 85 .

57 Foucault, Power/Knowledge, 146-65.

$5^{8}$ The company also paid for the furniture and eventual repairs, which were recorded in detail. See Ronaldo André Rodrigues da Silva, "Empresa, cidade e sociedade: Uma (re) construção das relações sociais sob o olhar das vilas operárias," in Anais do i encontro em patrimônio industrial (Campinas: UNICAMP, 2004), n.p.

59 The term "educationalization" was coined by Marc Depaepe and Paul Smeyers; see their "Educationalization as an Ongoing Modernization Process," Educational Theory 58 (2008): $379-89$.

6o Fabio José Martins de Lima, "Por uma cidade moderna: Ideários de urbanismo em jogo no concurso para Monlevade e a realização da nova cidade operária (1934-1960)," in Simposio A organização do territorio pelo capital, o caso das vilas e núcleos gerados por empresas, São Paulo, vol. 1 (Rio de Janeiro: Fundação Biblioteca Nacional, 2004), n.p. See also Rodrigues da Silva, "Empresa, cidade e sociedade."

61 Between 1920 and 2005, Belgo-Mineira employed 156 foreigners from 12 different countries, with Luxembourgers representing the majority of foreign workers. See Polanczyk, Louis Ensch e a Belgo-Mineira, 101.

62 Ibid., 100; Moyen, A história da Companhia Siderúrgica Belgo-Mineira, $5^{8}$. 


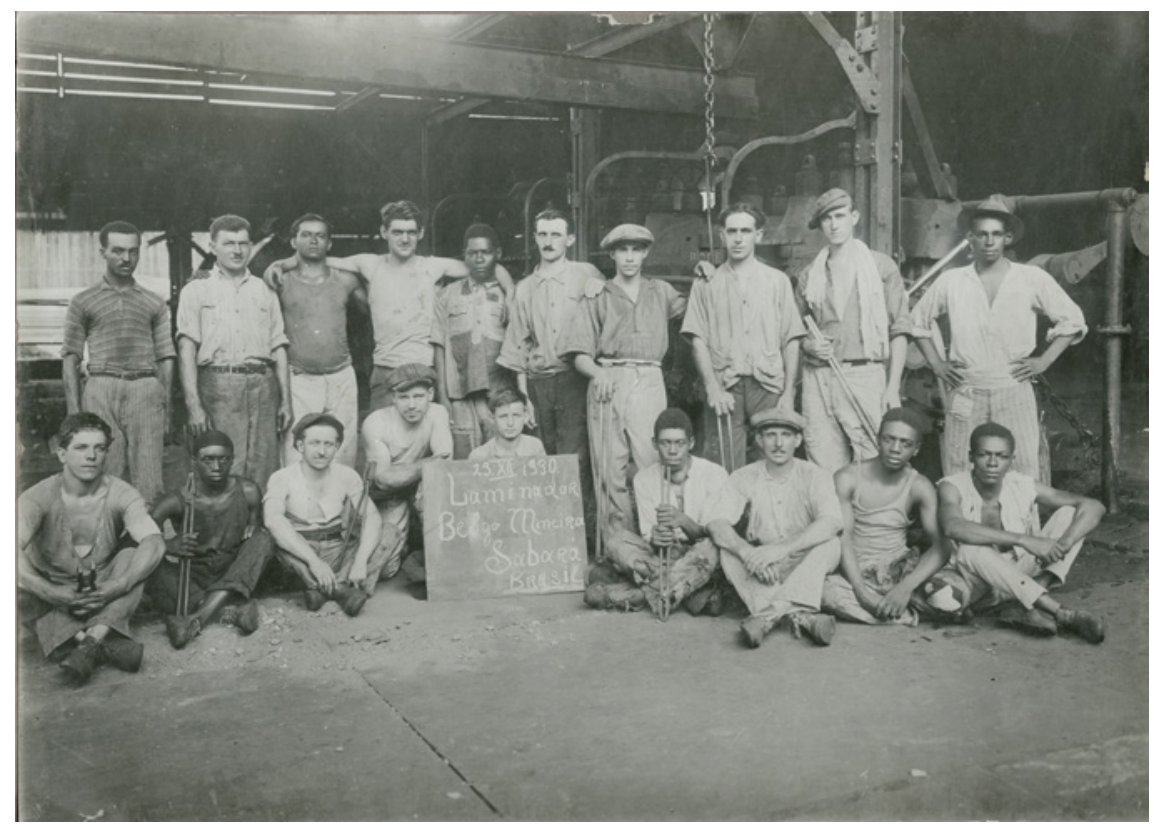

FIGURE 7.1 Rolling mill operators, Belgo Mineira, Sabará, Brazil, December 23, 1930. (C) PHOTOGRAPH BY IGINO BONFIOLI, BELO HORIZONTE. CENTRO DE MEMÓRIA DA ARCELORMITTAL BRASIL, SABARÁ.

Since the success of Belgo-Mineira depended on high-quality products that could be produced only by skilled workers, the transformation from 'simple' to skilled and educated men was to occur under Ensch's surveillance at BelgoMineira, or what he called "The Steel University of Brazil."63 Ensch and his colleagues, the highly qualified and well-behaved Luxembourgers, served as role models for the rest of the workers, as François Moyen, a former director of Belgo-Mineira, emphasized in an interview he gave in 2010: "We were the school for the others. We communicated the Luxembourgian virtues: to be 'honest and well-behaved.' We were at the top. Our people have an enormous amount of merits. ... At the time, we were unbeatable. We built schools, we were a role model in the social sector." 64

63 This 'concept' of the steel company as a university has been often repeated. See, for example, "Traz a morte de Louis Ensch," O Cruzeiro, October 21, 1953, Centro de Memória da ArcelorMittal Brasil, Sabará; "Velha Guarda. Professor Francisco José Pinto de Souza," $O$ Pioneiro 19 (1955), Centro de Memória da ArcelorMittal Brasil, Sabará.

64 “Der Mann, der Belgo Mineira prägte," Tageblatt, December 2, 2010, http://www.tageblatt. lu/wirtschaft/story/95847883. 
These efforts to educate the workforce and transform simple men into skilled men - to make them "internalize the correct behavior," or to "normalize" individuals—also involved school education. ${ }^{65}$ By 1953, João Monlevade boasted three elementary schools and one vocational school, attended by thousands of students. By 1961, 9o percent of the population of Joâo Monlevade was literate. Primary, secondary, and professional schools at the time counted around 5,00o students, a greater number than there were workers at the João Monlevade plant. ${ }^{66}$ Special attention was given to vocational training at the Escola Profissional de Monlevade — or "The Work Academy," as it was called in O Pioneiro. ${ }^{67}$ Based on the SENAI (Serviço Nacional de Aprendizagem Industrial, National Industrial Training Service) model of education created by the Brazilian government, this vocational school "focused on training as a vehicle for discipline, social control, and worker integration into the state-directed project for national development." ${ }^{\prime 8}$ Indeed, this kind of training certainly benefited Ensch's ideas of creating a productive workforce. The company's investments in vocational schools made it possible to "adapt the training to the needs of industry, without government interference." 69 This way, the investment in vocational training as a "technology of power" and discipline met the demands of production. Along with mechanics, welding, design, and other practical, hands-on subjects, the students also learned discipline. ${ }^{70}$

With the housing and schooling projects in place, the only social initiatives still missing were in the field of health. Like the Mayrischs in Luxembourg, Ensch spent much effort and money to establish and promote health reform. In 1947, Ensch married Maria (“Ceci”) Campos Coutinho (1910-1966), a Francophile Brazilian who helped him in his endeavors, especially in the health

65 Gary L. Anderson and Jaime Grinberg, "Educational Administration as a Disciplinary Practice: Appropriating Foucault's View of Power, Discourse, and Method," Educational Administration Quarterly 34, no. 3 (1998): 335.

66 "Afirmou o sr. Magalhaes Pinto, ao inaugurar o quarto escolar de Monlevade, construído pela Belgo Mineira," Estado de Minas, April 18, 1961, 3, Centro de Memória da ArcelorMittal Brasil, Sabará.

67 "Escola Profissional - Academia de Trabalho!" O Pioneiro 5 (1955), Centro de Memória da ArcelorMittal Brasil, Sabará. The school's pedagogical/educational rhetoric and associated practices are quite similar to the educational discourses and practices developed, from 1914 onwards, at the Institut Emile Metz, a progressive vocational school in Luxembourg. For more information about the Institut Emile Metz, see Herman, "Forging Harmony in the Social Organism."

68 Barbara Weinstein, "The Industrialists, the State, and the Issues of Worker Training and Social Services in Brazil, 1930-50," The Hispanic American Historical Review 70, no. 3 (1990): 392.

69 Ibid., 394.

$70 \quad$ See Companhia Siderurgica Belgo Mineira, n. p. 
sector. ${ }^{71}$ At the 25th anniversary celebration of Ensch's directorship, plans were presented in Sabará for the construction of the "Sanatorium Ceci," giving visibility to the social works of his wife. ${ }^{72}$ In addition, Ensch built one of the most modern and best-equipped hospitals in Brazil, the Hospital Margarida, named after his mother. The company also built crèches, childcare stations, milk distribution and production centers, and dental clinics. Similar to the activities of the Luxembourg Anti-Tuberculosis League, these places also served as health education and prevention centers providing information on diseases such as malaria.

Belgo-Mineira also launched a number of social and sports clubsincluding a fishing and hunting club, a successful football team, and sports and leisure clubs for women. The company had its own swimming pool and even built vacation houses for its workers. By tightening his control over the workers' personal behavior, including their leisure activities, Ensch was therefore able to transform his miners into more cultivated workers. ${ }^{73}$ Participating in these social and sports clubs also created a feeling of pride among the workers. Having a healthy and strong athletic body meant being able to operate heavy machinery and to produce as much steel as possible. Those who produced more were also more highly valued in society. In fact, physical strength and health were often a precondition for becoming a member of the Belgo-Mineira workforce and of utmost importance to Ensch, who, as one former worker recalled, would handpick the workers himself: "Dr. Louis Ensch would come down from his residence to the plant and remove from the queue the candidates who were not old or fit enough to work. So I, a 12-year-old, was removed from the queue." 74

Depending on their physical condition, many miners started working at Belgo-Mineira between the ages of 11 to 15, but most of them came into contact with the company at a much earlier age. As children, they regularly 'trespassed' to play on the plant's premises or to bring lunch to their fathers who were their role models. In almost all cases, several generations of a family worked for the company. Since Belgo-Mineira was so overwhelmingly involved in all spheres

71 For more information about Maria Coutinho, see Azevedo, Relances da Belgo-Mineira, 38.

72 The sanatorium, however, was never opened, most probably because of Ensch's sudden death in 1953. See Companhia Siderurgica Belgo Mineira, n.p.

73 John D. Rockefeller advocated similar activities in Colorado. See Robin C. Henry, "In Order to Form a More Perfect Worker: John D. Rockefeller Jr. and Reform in Post-Ludlow Southern Colorado," in Making an American Workforce: The Rockefellers and the Legacy of Ludlow, ed. Fawn-Amber Montoya (Boulder: University of Colorado Press, 2014), 85 .

74 “Concurso de memória empresarial 'Foi assim,”' F.V. ooo1, Centro de Memória da ArcelorMittal Brasil, Sabará. 
of the workers' lives, it was natural that already the very young dreamed of becoming a part of it: "As we walked home [from the plant] ... our hearts were filled with the dream of one day belonging to that production system! It was at this epoch that the steel men were forged, men that made this company a world leader in steel production. And the dream came true."75

In a relatively short period of time, Ensch not only managed to create an "industrial mentality"; he and his company actually achieved much more: the workers' complete identification with the company. The attachment to the company was so overwhelming that some of the workers did not like to have days off, waiting impatiently to go back to work. ${ }^{76}$ The feeling of belonging to the company gradually became so strong that one often comes across statements such as "I live from work and for work," "I was born to work," or "I intend to leave this company only when I die." ${ }^{77}$ Some even referred to the company as "Mãe Belgo" (Mother Belgo). ${ }^{78}$ From fostering dreams of becoming a part of (children of) Belgo to offering practical work that would help make these dreams come true, Ensch and his company thus were able to develop a "workers' personality" characterized by discipline and humility, high moral and intellectual values, obedience, and pride in being a workman and ultimately an exemplary citizen.$^{79}$ One worker recalled:

I was born in 1921 ... I grew up with the dream of becoming a "worker" and participating in building a better Brazil. ... To be a citizen and to exercise my citizenship, while being a resident of a [workers'] village, I dreamed of having work that would support me and my family. ... Through my work I was able to achieve my dreams, I raised a family, I was able to buy

75 “Concurso de memória empresarial ‘Foi assim,” N.S.E.L. ooo1, Centro de Memória da ArcelorMittal Brasil, Sabará.

$7^{6}$ The following statement is a good example: "I enjoy working. Thank God I am not working for the money; my work pays off because I like it. On vacation, I rest well the first two days and then I desperately want to go back to the plant." Cited in "Velha Guarda: Trabalho não me mete mêdo," O Pioneiro 16 (1955), Centro de Memória da ArcelorMittal Brasil, Sabará.

77 "Velha Guarda: Pintou tôdas as maáquinas e edifícios da Usina Siderúrgica," O Pioneiro 24 (1955); "Velha Guarda: Raimundo Caetano Silva: nasceu no dia do trabalho," O Pioneiro 25 (1955); "Velha Guarda: Só pretendo sair da Usina quando morrer," O Pioneiro 6 (1955), Centro de Memória da ArcelorMittal Brasil, Sabará.

78 “Concurso de memória empresarial ‘Foi assim,” E.P.A.V. ooo1, Centro de Memória da ArcelorMittal Brasil, Sabará.

79 "Workers' personality" is the term used by Timo Luks; see Timo Luks, "Social Engineering, the Factory and Urban Environment: Cadbury/Bournville and Opel/Rüsselsheim (18781960)," in Zimmermann, Industrial Cities, 268. 
a home and educate my children. I lived with dignity and was proud to tell everyone that I was a part of Belgo Mineira. ${ }^{80}$

The educational and social initiatives that created disciplined and productive men thus served yet another purpose. Being part of a company that is "building a better Brazil," Belgo-Mineira also made its workers feel like proper citizens of their country. ${ }^{81}$ The company's many private initiatives thus gradually contributed to the "construction of a new image of the industrialists as progressive and enlightened and ready to create an alliance with labor in the name of national development." 82

\section{$5 \quad$ Summary and Discussion}

The steel company ARBED, created in 1911, was the main source of the Grand Duchy's economic and social prosperity. Its founding family, the Mayrischs, launched a series of social initiatives in the fields of housing, health, and education to improve the health and living conditions of their workers. These initiatives were not based solely on philanthropic motivations. Their goal was to build worker loyalty to the company and thus assure productivity and economic prosperity. However, ARBED's path to success was not always smooth, particularly when Luxembourg's exit from the German Customs Union after World War I made it more difficult to export steel produce. It was during these hard times that ARBED's idea of expanding to Latin America was born. In 1921, ARBED established a subsidiary company, the Companhia Siderúrgica BelgoMineira, in the city of Sabará in the Brazilian state of Minas Gerais. Along with its steel producing expertise, ARBED also exported its social welfare ideas that it considered the basis for economic profit. One man in particular, Louis Jacques Ensch, who was put in charge of the business in Brazil, took the role of social benefactor and adapted these ideas to the new context, trying to create an obedient and disciplined work force for his newly created steel empire in Minas Gerais.

\footnotetext{
80 "Concurso de memória empresarial 'Foi assim," J.P.F. ooo1, Centro de Memória da ArcelorMittal Brasil, Sabará.

81 This was repeated over and over in local media reports on Belgo-Mineira's activities. See, for example, "Jubileu de Ouro da C.S.B.M," Atualidades do Vale do Piracicaba: Orgão da Associação Monlevade de Serviços Sociais 150 (December 11, 1972), Centro de Memória da ArcelorMittal Brasil, Sabará.

82 Weinstein, "The Industrialists, the State," 401.
} 
Ensch's first and biggest task was to instill in his as yet unskilled workers an "industrial mentality" to keep them at work. Between 1930 and 1953, he launched a host of social initiatives, which included the construction of an entire industrial city, João Monlevade, from scratch. While these social initiatives definitely improved workers' lives and health, they also served to transform the workers from simple and uneducated people into skilled, obedient, and disciplined laborers. In order to advance and maintain a social model that guaranteed stability and to create an industrial mentality, Ensch used his social initiatives as educational tools. ${ }^{83}$ From inspecting workers' houses to handpicking future workers to creating vocational schools that taught discipline along with practical work, Ensch's personal involvement in transforming simple miners or farmers into skilled steel workers remains a fascinating case study. As a result of Ensch's social reform initiatives, Belgo-Mineira penetrated every aspect of its workers' lives. Social initiatives and creating emotions such as fear, pride, and belonging served as "technologies of power" and modes of governing.

Among the obvious positive effects of these social initiatives was the fact that Minas Gerais became a highly literate and one of the richest Brazilian states during Ensch's era. At the same time, Ensch could realize his desire to become as great a pioneer as those he had learned from in Luxembourg, a "progressive and enlightened industrialist" glorified for his achievements. ${ }^{84}$ He indeed managed to put Brazil on the world map of steel industries, create long-lasting political and economic ties between Brazil and Luxembourg, and provide a satisfying living environment for the people who were the basis of Belgo-Mineira's success. The impact of Belgo-Mineira on the national economy cannot be denied either. It therefore became natural for men who were a part of the company to feel like they were contributing to the development of their country. In this way, a private initiative contributed to the contemporary national discourse promoting the modernization of Brazil.

Still, in order to understand Belgo-Mineira's success, it is necessary to reflect on the processes of establishing this modern steel production company and to question what has been called the "Brazilian specificity of quiet absorption, slow fusion and even peaceful amortization of foreign influences and claims." ${ }^{85}$ Although it is difficult to find any information that explicitly shows any resistance to Belgo-Mineira's ideas of social and economic welfare, one should not assume that there was no resistance at all. Before João Monlevade was fully operational in the late 1930s, Belgo-Mineira had difficulty getting its miners to show up for work. This was attributed to the "lack of industrial mentality" in

\footnotetext{
83 Rodrigues da Silva, "Empresa, cidade e sociedade."

84 Weinstein, "The Industrialists, the State," 401.

85 Stols, "Présences belges et luxembourgeoises," 160.
} 
Sabará, where the company initially operated.$^{86}$ It might be argued, however, that it also testifies to the workers' "passive resistance" to the transformation of life and society that came with these new industrial developments. ${ }^{87}$ With the construction of the industrial city of João Monlevade, however, the workers' attitudes towards their work place seem to have changed completely. Now, the workers no longer wanted to stay away from the plant; they "lived from work and for work" and were proud to be part of a company that contributed to the nation's economic development. ${ }^{88}$ How did this transformation occur? I have tried to show in this essay that this transformation was linked to Ensch's personal involvement and his methods of discipline, meritocracy, and control, which he used as "technologies of power" and governance.

It is equally important, however, to mention that the image the company projected, or sought to project, created a glorifying discourse that eventually seems to have become the only reality for the inhabitants of Belgo-Mineira's industrial cities. Like ARBED in Luxembourg, Belgo-Mineira actively promoted a certain image. Its social initiatives were much photographed, often by famous photographers such as Igino Bonfioli. ${ }^{89}$ They were also the subject of various promotional materials and films promoting the steel industry. ${ }^{90}$ Moreover, Belgo-Mineira had its own biweekly magazine called $O$ Pioneiro, which was mostly dedicated to the promotion of the company's philanthropic work and contributions to the national economy. The examples from OPioneiro presented in this paper nicely document the positive attitudes of the company's workers and employees, but since the magazine was published by and for Belgo-Mineira, it is, of course, necessary to acknowledge its bias. ${ }^{91}$ Moreover, the difficulty

\footnotetext{
86 Moyen, A história da Companhia Siderúrgica Belgo-Mineira, 59.

87 Foucault, Power/Knowledge, 163.

88 "Velha Guarda: Pintou tôdas as maáquinas e edifícios da Usina Siderúrgica," O Pioneiro 24 (1955).
}

89 Igino Bonfioli (1886-1965) was an Italian film producer, director, cinematographer, and photographer. Born in Verona, Italy, he migrated to Brazil when he was 11 years old. Bonfioli lived and worked in Minas Gerais most of his life and died in Belo Horizonte, MG, Brazil. One of his best-known films is A Canção da Primavera (1923). See Alexandre Pimenta Marques, "O registro inicial do documentário mineiro: Igino Bonfioli e Aristides Junqueira" (master's thesis, Escola de Belas Artes da UFMG, 2007).

9o For example, the book published on the occasion of the 25th anniversary celebration of Ensch's administration glorifies the initiatives both textually and visually. See Companhia Siderúrgica Belgo Mineira. Some of the films are available online; see, for example, "Qualidade da Educação em João Monlevade/Sabará na década de 40," https://www.youtube. $\operatorname{com} /$ watch? $\mathrm{v}=\mathrm{qgbg}_{2} \mathrm{wO}_{5} \mathrm{~T}_{4} \mathrm{E} \& \mathrm{t}=4 \mathrm{~s}$.

91 At the same time, we cannot fully discredit the workers' positive testimonies, since the information collected independently of the company's direct influence—-such as the "Foi assim" essays written by former Belgo-Mineira employees many years later-by and large corroborate the ideas expressed in $O$ Pioneiro. 
to find evidence of workers' resistance also suggests that the company wanted to preserve the positive image only. We know, for example, that workers' protests occurred in João Monlevade around 1945, even though the city was always presented as a utopian city in which dreams come true. ${ }^{92}$ It is, however, extremely difficult to find more detailed information about these protests. More research is needed to fill these gaps and to challenge the corporate narrative of the creation of a disciplined and contented workforce, while acknowledging the obvious benefits that industrialization brought to Minas Gerais.

\section{Acknowledgments}

An earlier version of this paper was presented at ISCHE 38 at Loyola University, Chicago, IL. I am grateful to my supervisor Dr. Karin Priem, the other members of the FAMOSO team, and the participants of the conference for their generous support and comments. I would also like to thank Marc André Meyers, who first drew my attention to Belgo-Mineira, and Isabella Menezes, who facilitated access to the archives of the Centro de Memória da ArcelorMittal Brasil in Sabará and continues to be a great support.

\section{Sources and Bibliography}

\section{Archival Sources}

$\mathrm{AE}$ (Ministère des Affaires Étrangères) Collection, Archives nationales de Luxembourg (ANLux).

Centro de Memória da ArcelorMittal Brasil, Sabará, Minas Gerais, Brazil.

\section{Primary Sources}

A memória de Louis Jacques Ensch. Belo Horizonte: Estabelecimentos Gráficos Santa Maria, 1953 .

ARBED. CEuvres sociales. Luxembourg: Victor Bück, 1922.

"Ausflug der Rhamkinder ins Minettebassin." Luxemburger Wort, July 9, 1949.

Companhia Siderúrgica Belgo Mineira. Rio de Janeiro: Gráficos Bloch, 1953.

Lentz, Jean J. La lutte contre la tuberculose dans le Grand-Duché de Luxembourg: Etude sociale et recueil des textes. Luxembourg: Imprimerie de la Cour Joseph Beffort, 1934. Société luxembourgeoise d'hygiène sociale et scolaire. Einiges über Wohnungsverhältnisse der ärmeren Arbeiterbevölkerung in Luxemburg. Luxembourg: M. Huss, 1907.

92 Moyen, A história da Companhia Siderúrgica Belgo-Mineira, 65. 


\section{Bibliography}

Anderson, Gary L., and Jaime Grinberg. "Educational Administration as a Disciplinary Practice: Appropriating Foucault's View of Power, Discourse, and Method." Educational Administration Quarterly 34, no. 3 (1998): 329-53.

Arcelor Mittal, ed. La sidérurgie luxembourgeoise: Un siècle d'histoire et d'innovation/ Steelmaking in Luxembourg: A Century of History and Innovation. Luxembourg: ArcelorMittal, 2011.

Azevedo, Édio Vieira de. Relances da Belgo-Mineira. Belo Horizonte: MG—SEGRAC, 2004.

Barros, Gustavo. "O desenvolvimento do setor siderurgico brasileiro entre 1900 e 1940: criaçao de empresas e evoluçao da capacidade produtiva." Revista de Historia Economica \& Economia Regional Aplicada 9, no. 14 (Jan-Jun 2013): 9-32.

Barthel, Charles, and Josée Kirps, eds. Terres rouges: Histoire de la sidérurgie luxembourgeoise. 6 vols. Luxembourg: Centre d'études et de recherches européennes Robert Schuman/Archives nationales de Luxembourg, 2009-2018.

Bolz, Cedric. "Constructing Heimat in the Ruhr Valley: Assessing the Historical Significance of Krupp Company Housing from Its Origins through the National Socialist Era, 1855-1941." PhD dissertation, University of Victoria, 2003.

Bueno, Fernanda. "Estruturas metalicas do inicio do periodo do industrializacao em Minas Gerais: Decorrencias e Preservacao." Master's thesis, Federal University of Ouro Preto, 2012.

Buschmann, Walter. Zwischen Rhein-Ruhr und Maas: Pionierland der IndustrialisierungWerkstatt der Industriekultur. Essen: Klartext, 2013.

Chômé, Félix. ARBED: Un demi-siècle d'histoire industrielle 1911-1964. Luxembourg: ARBED, 1972.

Correia, de Barros, Telma. "Modernismo e o núcleo fabril: o anteprojeto de Lúcio Costa para Monlevade." Paper presented at the vi Seminário de História da Cidade e do Urbanismo, Natal, Brazil, 2000.

Depaepe, Marc, and Paul Smeyers. "Educationalization as an Ongoing Modernization Process." Educational Theory 58 (2008): 379-89.

"Der Mann, der Belgo Mineira prägte." Tageblatt, December 2, 2010. http://www.tageb latt.lu/wirtschaft/story/95847883.

Dittrich, Klaus. "Selling Luxembourgian Steel in Japan: Columeta Tokyo, 1925 to 1941." Zeitschrift für Unternehmensgeschichte 61, no. 2 (2016): 215-36.

Fayot, Ben. "Merci au 'Minettsdapp'!" Forum 304 (2011): 39.

Foucault, Michel. Power/Knowledge: Selected Interviews and Other Writings, 1972-1977. Translated by Colin Gordon. New York: Pantheon, 1980.

Gall, Lothar. Krupp:Der Aufstieg eines Industrieimperiums. Berlin: Siedler, 2000.

Goetzinger, Germaine. Aline Mayrisch: Féministe engagée, philanthrope éclairée, femme de lettres éminente. Metz: n. p., 2014. 
Goniva, Jean. "The Emergence of Modern Steelmaking in the 19th Century." In Arcelor Mittal, La sidérurgie luxembourgeoise, 15-20.

Hadzalic, Irma. "Sick and Weak but Made of Steel: Luxembourgian Open-Air Schools and Other Responses to the Spread of Tuberculosis at the Beginning of the 2oth Century." Revista da História e Historiografia da Educação 1, no. 1 (2017): 44-64.

Henry, Robin C. "In Order to Form a More Perfect Worker: John D. Rockefeller Jr. and Reform in Post-Ludlow Southern Colorado." In Making an American Workforce: The Rockefellers and the Legacy of Ludlow, edited by Fawn-Amber Montoya, 81-102. Boulder: University of Colorado Press, 2014.

Herman, Frederik. "Forging Harmony in the Social Organism: Industry and the Power of Psychometric Techniques." History of Education 43, no. 5 (2014): 592-614.

Herman, Frederik, and Ira Plein. "Envisioning the Industrial Present: Pathways of Cultural Learning in Luxembourg (1880s-1920s).” Paedagogica Historica 53, no. 3 (2017): 268-84.

“Historique." Lycée Technique Privé Emile Metz. http://www.ltpem.lu/php_links/ historique.php.

Levine, Robert M. Father of the Poor? Vargas and His Era. Cambridge: Cambridge University Press, 1998.

Lewis, Robert. "Networks and the Industrial Metropolis: Chicago's Calumet District, 1870-1940." In Industrial Cities: History and Future, edited by Clemens Zimmerman, 89-114. Frankfurt: Campus Verlag, 2013.

Lima, Fabio Jose Martins de. "Por uma cidade moderna: Ideários de urbanismo em jogo no concurso para Monlevade e a realização da nova cidade operária (1934-1960)." In Simposio A organização do territorio pelo capital: o caso das vilas e núcleos gerados por empresas, São Paulo. Vol. 1. Rio de Janeiro: Fundação Biblioteca Nacional, 2004.

Lima, Fabio Jose Martins de. "Por uma cidade moderna: Ideários de urbanismo em jogo no concurso para Monlevade e a realização da nova cidade operária (1931-1943)." PhD diss., University of São Paulo, 2003.

Lima, Fabio Jose Martins de. "Urbanismo em Minas Gerais: Olhares de engenheiros, arquitetos, geógrafos e outros planejadores (1930-1980)." URBANA, Dossiê: Urbanistas e Urbanismo 5, no. 6 (March 2013): 148-69.

Lorang, Antoinette. "Les logements ouvriers: une cite modèle à Dudelange/A Model Workers' Housing Estate in Dudelange." In Arcelor Mittal, La sidérurgie luxembourgeoise, $153-55$.

Lorang, Antoinette. L'image sociale de l'Arbed à travers les collections du Fonds de logement. Luxembourg: Le fonds pour le développement du logement et de l'habitat, 2009 .

Luks, Timo. "Social Engineering, the Factory and Urban Environment: Cadbury/Bournville and Opel/Rüsselsheim (1878-196o)." In Industrial Cities: History and Future, edited by Clemens Zimmerman, 263-82. Frankfurt: Campus Verlag, 2013. 
Marques, Alexandre Pimenta. "O registro inicial do documentário mineiro: Igino Bonfioli e Aristides Junqueira." Master's thesis, Escola de Belas Artes da UFMG, 2007.

Marx, Jean. "LARBED, un pionnier de la formation professionnelle au Luxembourg/ ARBED, a Pioneer of Professional Training in Luxembourg." In Arcelor Mittal, $L a$ sidérurgie luxembourgeoise, 161-63.

Menezes, Carvalho de I. "Louis Jacques Ensch: A presença do engenheiro luxemburguês em Sabara." Revista do Instituto Historico e Geografico do Ciclo do Ouro 1, no.1 (December 2011): 72-77.

Meyers, Marc André. D'amour et d'acier: Quand le Luxembourg et le Brésil forgeaient l'histoire. Luxembourg: Ed. Saint-Paul, 2015.

Minnery, John. "Model Industrial Settlements and Their Continuing Governance." Planning Perspectives 27, no. 2 (April 2012): 309-21.

Moyen, François. A história da Companhia Siderúrgica Belgo-Mineira. Uma trajetória de crescimento consistente (1921-2005). Belo Horizonte: Acelor Brasil, 2007.

Neves, Ribeiro Osias, and Camisasca Mesquita Marina. Aço Brasil: uma viagem pela indústria do aço. Belo Horizonte: Escritório de Histórias, 2013.

Novella, Enric. "Germs, Bodies, and Selves: Tuberculosis, Social Government, and the Promotion of Health-Conscious Behavior in the Early Twentieth Century." In this volume.

“Qualidade da Educação em João Monlevade/Sabará na década de 40." https://www .youtube.com/watch?v=qgbg2 $\mathrm{wO}_{5} \mathrm{~T}_{4} \mathrm{E} \& \mathrm{t}=4 \mathrm{~s}$.

Petit, Joseph. Un grand Luxembourgeois: Louis Ensch. Luxembourg: Impr. P. Linden, 1953 .

Polanczyk, Antonio José. Louis Ensch e a Belgo-Mineira. Belo Horizonte: 3i Editora, 2014. Poos, Françoise. "Photography as Space for Constructing Subjectivities: Luxembourg's Steel Dynasties and the Modern Workforce as Seen through the Glass Plate Negatives from the Institut Emile Metz." In this volume.

Priem, Karin, and Geert Thyssen. "Fragmented Utopia: Luxembourgian Industrialists, Intellectual Networks and Social-Educational Reforms between Tradition and Avant-Garde." Jahrbuch für Historische Bildungsforschung 19 (2013): 106-26.

Reuter, Antoinette, and Claudio Cicotti. Rêves d'Italie, Italies de rêve: imaginaires et réalités autour de la présence italienne au Luxembourg et dans la Grande Région. Luxembourg: University of Luxembourg, 2008.

Ribeiro, Lins Gustavo. "Learning from Minas Gerais: Flows of Capital, Production, and Managerial Models Within the Steel Industry." In Industry and Work in Contemporary Capitalism: Global Models, Local Lives?, edited by Victoria Goddard and Susana Narotzky, 91-104. London: Routledge, 2015.

Rodrigues da Silva, Ronaldo André. "Empresa, cidade e sociedade: uma (re)construção das relações sociais sob o olhar das vilas operárias." In Anais do I Encontro em Patrimônio Industrial. Campinas: UNICAMP, 2004. 
Schmitz, Nadine. "La politique sociale de l'ARBED/ARBED's Social Policy." In Arcelor Mittal, La sidérurgie luxembourgeoise, $149-51$.

Schmitz, Nadine. "Le paternalisme d'Émile Mayrisch." In Barthel and Kirps, Terres rouges, vol. 3, 104-153.

Sintes, Hugo. Review of Philanthrocapitalism: How the Rich Can Save the World and Why We Should Let Them, by Matthew Bishop and Michael Green, and Just Another Emperor? The Myths and Realities of Philanthropic Capitalism, by Michael Edwards. Development in Practice 19, no. 6 (2009): 812-15.

Stols, Eddy. "Présences belges et luxembourgeoises dans la modernisation et l'industrialisation du Brésil (1830-1940)." In Brasil: Cultures and Economies of Four Continents, edited by Bart de Prins, Eddy Stols, and Johan Verberckmoes, 121-96. Leuven: Uitgeverij Acco, 2011.

Stumper, Robert. Colpach. Luxembourg: Amis de Colpach, 1957.

Stumper, Robert. Colpach. 2nd, rev. and exp. ed. Luxembourg: Amis de Colpach, 1978. Thill, Robert. "Suite" Brasileira: Mit der Baltic Sea (KLM) nach Rio de Janeiro. Bei den Luxemburgern in Minas Gerais. Separatabdruck der vom 19. November 1957 bis 1. Januar 1958 im Tageblatt erschienenen Reportage. Esch-sur-Alzette: Impr. Coopérative Luxembourgeoise, $195^{8}$.

Thyssen, Geert. "Engineered Communities? Industry, Open-Air Schools, and Imaginaries of Belonging (c. 1913-1963)." History of Education \& Children's Literature 10, no. 2 (2015): 297-320.

Thyssen, Geert. "The Open-Air Schools of Dudelange and Esch-sur-Alzette." Forum für Politik, Gesellschaft und Kultur 301 (2010): 40-42.

Thyssen, Geert, and Karin Priem. "Brains, Money and Power in Education: Industrial-Intellectual 'Avant-Gardes' and Their 'Social Works."' Unpublished conference paper, International Standing Conference for the History of Education (ISCHE), ISCHE 35, Riga, Latvia, August 21-24, 2013.

Trausch, Gilbert. L'ARBED dans la société Luxembourgeoise. Luxembourg: Imprimerie de la Cour Victor Buck, 2000.

Weinstein, Barbara. "The Industrialists, the State, and the Issues of Worker Training and Social Services in Brazil, 1930-50." The Hispanic American Historical Review 70, no. 3 (1990): 379-404.

Wey, Claude. "L'histoire des migrations entre le Luxembourg et les Amériques." In Retour de Babel: itinéraires, mémoires et citoyenneté, 31-40. Luxembourg: Editions Retour de Babel, 2007.

Wolfe, Joel. "'Father of the Poor' or 'Mother of the Rich'? Getúlio Vargas, Industrial Workers, and Construction of Class, Gender, and Populism in Sao Paulo, 1930-1954." Radical History Review 58 (1994): 80-111. 